\title{
NUTRITION VALUE OF WILD ANIMAL MEAT
}

\author{
Vita Strazdina, Aleksandrs Jemeḷjanovs, and Vita Šterna \\ Research Institute of Biotechnology and Veterinary Medicine "Sigra", Latvia University of Agriculture, \\ Institūta iela 1, Sigulda, LV-2150, LATVIA; \\ sigra@lis.Iv
}

Contributed by Aleksandrs Jemeljanovs

\begin{abstract}
One of the most valuable foods is meat, due its nutritional value, largely determined by the essential amino acids, fatty acids, vitamins, minerals, etc. At the same time, concern needs to be given to health of consumers by used products with less calories, which can be ensured by greater variety of game animals, including also deer grown in captivity. The aim of our investigation was to compare the nutrition value of elk, wild deer, farm deer, roe deer, and wild boar that were killed during hunting in Latvia. Meat samples (m. logissimus lumborum) were collected in the autumn-winter season. The results of the conducted research suggest that game meat samples have higher protein and essential fatty acid content in comparison with domestic animals. The amount of fat in all analysed samples did not differ greatly, although the fatty acid content in wild game meat differed significantly. The fatty acid profile was used to calculate the atherogenicity index (Al), which has a positive correlation with the risk of cardiovascular disorders. The formula $A I=[C 12: 0+(C 14: 0 \times 4)+C 16: 0] /($ Total unsaturated fatty acids) was used to calculate the ratio of total saturated fatty acids, $\omega-6$ and $\omega-3$. Regarding the microelement content of meat there were great differences in iron and manganese concentration among animals.
\end{abstract}

Key words: hunting animals meat, healthy food.

\section{INTRODUCTION}

In recent years, in the Latvian population, public attention has been paid to the health and the value of it, which can be achieved using wholesome food. One of the most valuable foods is meat. In the "food pyramid" meat is one of the products that needs to be used moderately - about onefifth of all food. It provides the organism with wholesome, highly digestible proteins.

Protein varies among the meat animal species, and its content ranges between 13 and $23 \%$ of the fresh weight (Honikel, 2009). Our body uses $97 \%$ meat protein and $25 \%$ connective tissue.

The amino acid profile is important because some amino acids cannot be synthesised by humans and therefore must be supplied by the diet. Amino acids are divided into two groups: essential and substitutable. Essential amino acids are not synthesised in the body and therefore must be taken with food. If the diet lacks even one of the essential amino acids (such as tryptophan, lysine, methionine) the required protein synthesis is not possible. Meat is rich in the socalled essential or indispensable amino acids - lysine, leucine, isoleucine, and sulphur-containing amino acids — and in this sense meat has highly-quality protein (Young et al., 2001). Meat is also rich in B vitamins and is an important source of iron, phosphorus, copper and manganese. Depending on the type of meat fat content is $1-10 \%$ fat.

Meat has been identified, often wrongly, as a food having a high fat content and an undesirable balance of fatty acids. In fact, lean meat is very low in fat, with a content of 20-50 $\mathrm{g} / \mathrm{kg}$ (Wood and Enser, 2004). Game animals have a favourable balance between polyunsaturated and saturated fatty acids $(\mathrm{P}: \mathrm{S})$ and wild ruminants produce muscle with a desirable $\omega-6: \omega-3$ polyunsaturated fatty acid ratio.

Wild game meat is considered significant in the diet, and its share in consumption in recent years has increased. Currently, among consumers there is increased interest in meat from animals kept in conditions as close as possible to the natural ones. Such a requirement is undoubtedly fulfilled by game that is characterised by high nutritional value and specific sensory properties desired by consumers (Vergara et al., 2003; Soriano et al., 2006).

Game animals, such as elk (Alces alces), deer (Cervus elaphus), roe deer (Capreolus capreolus) and wild boar (Sus scrofa scrofa), every autumn and winter provide an excellent investment and diversification of many consumer meals. The statistics show that there are about 33000 hunters in the Latvian register, of which 17000 are active hunters. During the annual hunt, about 2789 tons (2712 - auxilliary service) of game meat is provided in Latvia (Data on 
number of hunted animals in 2010-2011 are from the State Forest Service official statistics).

The human body is composed of a broad range of chemical elements and their combinations, which must be in balance for us to feel good and be healthy. There are negative consequences for both under-and over-intake of a trace element (causing immune status and increased susceptibility to infections). The content of a trace elements in domestic meat products depends on the animal species and the quality of animal nutrition. Lack of minerals can be caused by animals age and physiological state, feed intake and housing conditions (Kalafova et al., 2003). In contrast, game animals move within an unlimited territory, and thus animal products contain all trace elements in sufficient quantities, but which varies according to the functional status of the body. The aim of our investigation was to compare the nutrition value of elk, wild deer, farm deer, roe deer, and wild boar that were killed during hunting in Latvia.

\section{MATERIALS AND METHODS}

Chemical analyses were conducted on a total of 54 meat samples (m. logissimus lumborum): elk (8), deer (18), roe deer (16), wild boar (12) collected after hunts throughout Latvia in the autumn-winter season (2008-2012). The analyses were conducted at the laboratory of Biochemistry and Microbiology of the Research Institute of Biotechnology and Veterinary Medicine „Sigra”. In the studied samples, protein, amino acids, fat, fatty acids, cholesterol content and micronutrient concentrations were determined. Samples were prepared within 48 hours after slaughtering or hunting. Meat samples of about $300 \mathrm{~g}$ were homogenised with a BÜCHI B-400 (ISO 3100-1).

Protein concentration was determined as total nitrogen content by Kieldahl method and using coefficient 6.25 for calculation (ISO 937:1974).

For determination of amino acids concentration, dried, defatted meat samples were treated with constant boiling $6 \mathrm{~N}$ hydrochloric acid in an oven at around $110{ }^{\circ} \mathrm{C}$ for $23 \mathrm{~h}$. Hydrolysate was diluted with $0.1 \%$ formic acid. Samples (2 $\mathrm{ml}$ ) were filtered using a siringe filter with a $0.45 \mu \mathrm{m}$ nylon membrane. Amino acid concentrations were determined using a reverse-phase HPLC/MS (Waters Alliance 2695, Waters 3100, column XTerra MS C18 $5 \mu \mathrm{m}, 1 \times 100 \mathrm{~mm}$ ): mobile phase (90\% acetonitrile: $10 \%$ dejonized water) $0.5 \mathrm{ml}$ $\min ^{-1}$, column temperature. $40{ }^{\circ} \mathrm{C}$. Data acquisition was conducted using the programme Empower pro.

Intramuscular fat concentration was determined by Sochlet method with hydrolysis procedure (boiling in hydrochloric acid) using SoxCap 2047 and SOX TEH 2055 equipment (FOSS) (LVS ISO 1443:1973).

Cholesterol concentration was determined by Blur colorimetric method using a spectrometer (Шманенков и Алиев, 1973).
Fatty acid analysis of meat. Homogenised meat samples were prepared for GLC (gas-liquid chromatography) analysis using direct saponification with $\mathrm{KOH} / \mathrm{methanol} \mathrm{followed}$ by derivatisation with (trimethylsilyl) diazomethane using the method of Aldai et al. (2006) An ACME, model 6100, GLC (Young Lin Instrument Co.) equipped with a flame ionisation detector, and an Alltech AT-FAME analytical column (fused silica $30 \mathrm{~m} \times 0.25 \mathrm{~mm}$ i.d.) was used. The individual FAMEs (fatty acid methyl esters) were identified according to similar peak retention times using standard mixture Supelco 37 Component FAME Mix.

From the fatty acid profile, the atherogenicity index (IA), a parameter proposed by Ulbricht and Southgate (1991), which has a positive correlation with risk of cardiovascular disorder, was calculated. The calculation was as follows:

$\mathrm{AI}=[\mathrm{C} 12: 0+(\mathrm{C} 14: 0 \times 4)+\mathrm{C} 16: 0] /($ Total unsaturated fatty acids).

The relative proportions of total saturated fatty acids and unsaturated $\omega-6$ and $\omega-3$ fatty acids were calculated.

Micronutrient concentrations in meat were measured according to ISO 6869-2002. The methods are based on flame atomic absorption using a spectrometer AAnalyst 200.

The experimental design was randomised and data were evaluated by analysis using SPSS 17. One-way ANOVA was used for comparison of mean values. Statistical significance was set at $P<0.05$. The biochemical composition (protein, fat, cholesterol, fatty acids, amino acids and trace elements) of wild game meat was determined as the amounts in $100 \mathrm{~g}$ of meat. Beef and pork samples were included for comparison (previously determined in the Research Institute of Biotechnology and Veterinary Medicine in Latvia SIGRA, unpublished data).

\section{RESULTS}

Proteins are an important part of our diet. All animal species given in Table 1 are excellent high-quality sources of protein. Protein concentration in game meat samples varied from 22.36 till $22.92 \%$. The results of the statistical analysis showed that the total protein concentration in the ruminants meat did not differ significantly $(F=1.286 ; P>0.05)$.

All of the animal species in the table has a low fat concentration $(1.33-1.90 \%)$ in meat samples (m. logissimus

Table 1

BIOCHEMICAL COMPOSITION OF GAME MEAT

\begin{tabular}{|c|c|c|c|c|}
\hline Group & $\mathrm{n}$ & Protein, \% & Fat, \% & 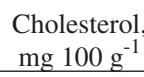 \\
\hline Elk & 8 & 22.72 & 1.33 & 64.41 \\
\hline Deer & 18 & 22.36 & 1.90 & 70.57 \\
\hline Roe deer & 16 & 22.82 & 1.59 & 67.92 \\
\hline Wild boar & 12 & 22.92 & 2.82 & 95.07 \\
\hline Beef & 15 & 19.61 & 1.48 & 76.31 \\
\hline Pork & 15 & 21.32 & 2.77 & 67.85 \\
\hline
\end{tabular}


lumborum), not only in ruminants, but also in wild boar meat $2.82 \%$.

Cholesterol found in muscles is free cholesterol and it is not related to that in animal blood, i.e. "good" or "bad" cholesterol. It is found in both fat and muscle in the range 64.41 to $95.07 \mathrm{mg} 100 \mathrm{~g}^{-1}$ among animal species (Table 1). From a nutritional point of view, in terms of cholesterol, none of ruminant meats is superior (preferred) over others. The exception is wild boar meat, in which higher cholesterol levels can be explained by the high level of adrenaline under stress during the hunting season. The cholesterol levels statistically differed between animals $(\mathrm{F}=2.55, P<0.05)$

The human body requires the essential amino acids lysine, isoleucine, phenylalanine, tryptophan, leucine, methionine, threonine, and valine. Each of these amino acids have a role in the human body. The concentrations of essential amino acids in game meat samples are shown in Figure 1.

Game muscle protein contains all essential necessary amino acids. Wild deer, roe deer and elk meat samples are similar in the summed concentrations of essential amino acids, suggesting that the diet of ruminants is sufficient in late autumn to winter (Fig. 1). Wild boar and pork samples, differed most in the summed concentrations of essential amino ac-

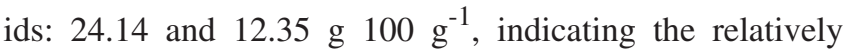
higher biological protein value of wild boar over pork.

Meat contains most of the essential fatty acids. Higher concentrations of saturated fatty acids are found in ruminant meat: $44 \%$ in cow and sheep. Lower concentrations of saturated fat are found in pork. These fat content of beef is greater than moose and roe deer meat (41\%) (Rule et al., 2002).

Composition of dietary fat is more significant for consumers than is total fat content. Therefore, composition of fatty acids, sum of saturated, monounsaturated, and polyunsaturated fatty acids was investigated (Table 2).

Results of investigation showed that lowest content of saturated fatty acids has meat samples of wild boar and elk meat samples - 34.79 and 35.75 , respectively. The highest sum of saturated fatty acids was found in deer meat samples $(42.13 \%)$, which is in agreement with Petkov (1986). Saturated fatty acids other than myristic, palmitic, and stearic

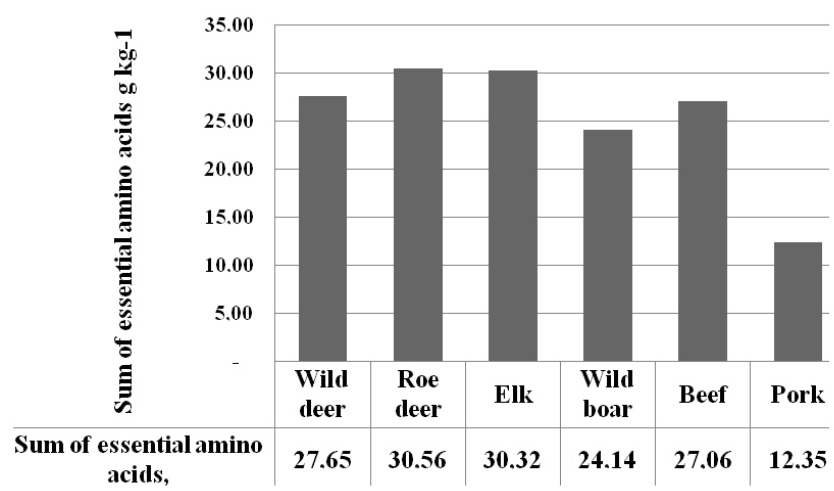

Fig. 1. Comparison of sums of essential amino acids in meat samples.
FATTY ACID COMPOSITION OF MEAT

\begin{tabular}{lcc|c|c|c|c}
\hline \multicolumn{1}{c}{ Fatty acid class } & Elk & Deer & $\begin{array}{c}\text { Roe } \\
\text { deer }\end{array}$ & $\begin{array}{c}\text { Wild } \\
\text { Boar }\end{array}$ & Beef & Pork \\
\hline Sum saturated (SFA) & $\mathbf{3 5 . 7 5}$ & $\mathbf{4 2 . 1 3}$ & $\mathbf{3 7 . 5 4}$ & $\mathbf{3 4 . 7 9}$ & $\mathbf{4 0 . 1 1}$ & $\mathbf{3 7 . 4 6}$ \\
Stearic (C 12: 0) & 0.19 & 0.30 & 0.01 & 0.11 & 0.24 & 0.15 \\
Myristic (C 14: 0) & 2.44 & 4.57 & 1.32 & 2.92 & 3.62 & 1.48 \\
Palmitic, (C 1: 0) & 18.08 & 21.02 & 18.72 & 23.12 & 21.43 & 26.65 \\
Sum mono-unsaturated & $\mathbf{3 4 . 0 9}$ & $\mathbf{2 6 . 5 7}$ & $\mathbf{2 8 . 9 6}$ & $\mathbf{3 5 . 6 3}$ & $\mathbf{3 4 . 6 0}$ & $\mathbf{5 0 . 8 7}$ \\
(MUFA) & & & & & & \\
Sum polyunsaturated & $\mathbf{1 8 . 9 7}$ & $\mathbf{2 3 . 4 7}$ & $\mathbf{2 5 . 3 8}$ & $\mathbf{1 7 . 2 5}$ & $\mathbf{1 5 . 3 6}$ & $\mathbf{5 . 9 5}$ \\
(PUFA) & & & & & & \\
Sum Omega-3* & 6.81 & 6.20 & 8.23 & 2.89 & 2.65 & 0.44 \\
Sum Omega-6** & 11.73 & 17.05 & 17.04 & 13.89 & 12.71 & 5.51 \\
Sum unsaturated & $\mathbf{5 3 . 0 6}$ & $\mathbf{5 0 . 0 4}$ & $\mathbf{5 4 . 3 4}$ & $\mathbf{5 2 . 8 8}$ & $\mathbf{4 9 . 9 6}$ & $\mathbf{5 6 . 8 2}$ \\
$\omega-6$ : $\omega-3$ & 1.72 & 2.75 & 2.07 & 4.81 & 4.8 & 12.52 \\
P : S ratio & 0.53 & 0.68 & 0.68 & 0.50 & 0.38 & 0.16 \\
Atherogenicity index AI & 0.53 & 0.79 & 0.44 & 0.66 & 0.82 & 0.58 \\
\hline * Linoleic and arachidonic acids & & & & \\
** Linolenic acid & & & & & & \\
& & & & & &
\end{tabular}

acids are found in extremely small amounts in meats. Conversely, myristic and palmitic acids may have a negative effect on cardiovascular health (Medeiros et al., 2002). Thus, myristic, palmitic, and stearic acids are the only saturated fatty acids presented in Table 2 . Regarding the concentrations of myristic acid (C $14: 0)$ and palmitic (C 16 : $0)$, lower concentrations of myristic acid (1.32\%) were found in roe deer meat compared to $4.57 \%$ and $3.62 \%$ in deer and beef meat, respectively. Palmitic acid concentration was the lowest in elk (18.08\%), followed by deer meat (18.72\%). Palmitic acid concentration was similar in deer and beef meat: $21.2 \%$ and $21: 43 \%$, respectively. Results of statystical analysis confirmed that summed SFA did not differ significantly $(P>0.05)$ among animals. The results showed that the PUFA:SFA ratio in game meat samples varied from 0.50 to 0.68 , and the ratio of $1-6: 1-3$ fatty acids varied from 1.72 to 2.75 .

The iron concentration in meat depends on the amount of fat and blood. Fe compounds in meat are utilised well by the human body. Meat samples of wild animal species contained iron from 1.300 to $5.04 \mathrm{mg} \mathrm{kg}^{-1}$. Manganese occurred at up to two times in game animal meat $(0.006$ to $\left.0.27 \mathrm{mg} \mathrm{kg}^{-1}\right)$ than in beef and pork samples $\left(0.09 \mathrm{mg} \mathrm{kg}^{-1}\right)$ (Fig. 3). The highest concentrations of zinc were observed in wild boar samples (2.560 to $4.200 \mathrm{mg} \mathrm{kg}^{-1}$ ) (Fig. 2). Copper concentrations were higher in beef $\left(0.39 \mathrm{mg} \mathrm{kg}^{-1}\right)$ and pork (0.410 mg kg-1) (Figs. 2, 3). All meats sampled were found to be excellent sources of trace elements.

\section{DISCUSSION}

The results of our investigation are similar with those of other studies: protein concentration in raw deer meat samples was reported as $21.7 \%$, in boar meat samples $21.9 \%$ (Paleari et al., 2003). Meat has most of the essential fatty 


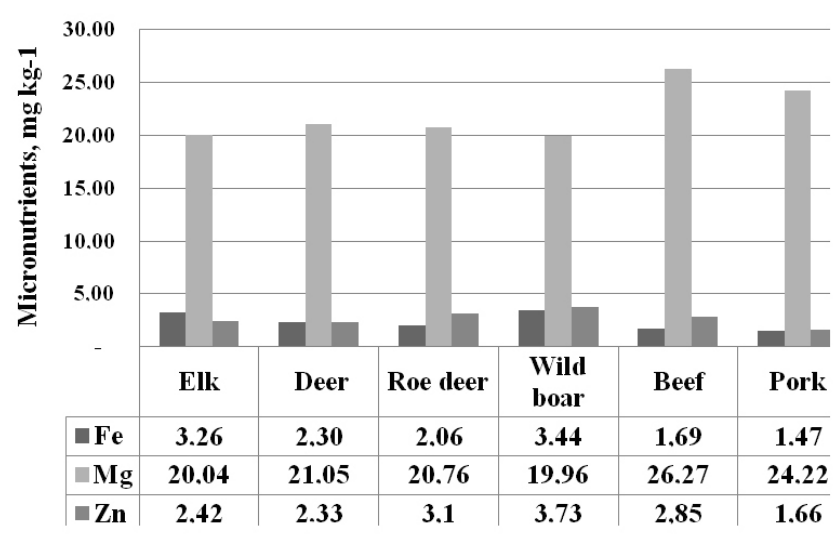

Fig. 2. Iron, magnesium, and zinc micronutrients composition of meat.

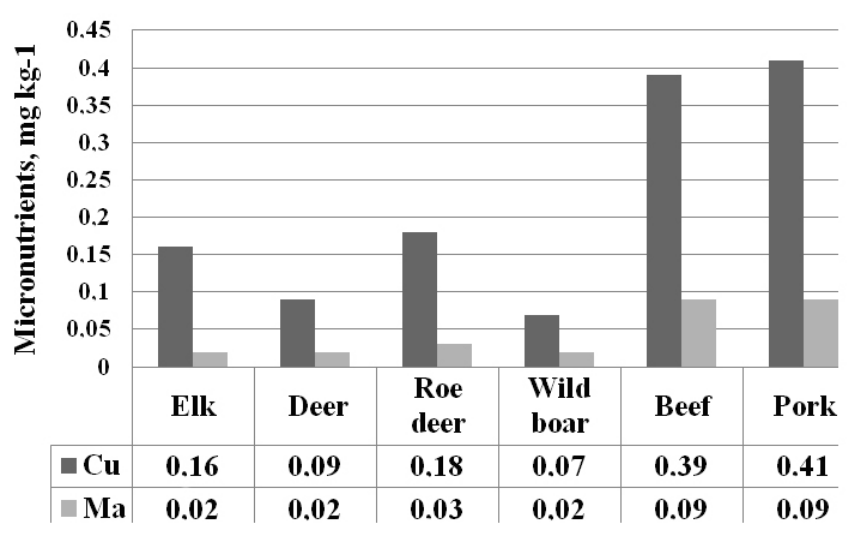

Fig. 3. Copper and manganese micronutrients composition of meat.

acids. Greater concentration of saturated fatty acids (44\%) is found in ruminant meat - cow, sheep. Less saturated fat is found in pork. The fat concentration in beef is greater than in moose and roe deer meat (41\%) (Rule et al., 2002). Wild game meat fats are more favourable to the human body, as the saturated fatty acid concentration is less, and polyunsaturated fatty acid concentration is higher (Cordan et al., 2002).

There are four interrelated factors that have important health ramifications: (1) the total fat content; (2) distribution of specific fatty acids; (3) the ratio of PUFA:SFA; and (4) the ratio of $\omega-6: \omega-3$ fatty acids. Each of these dietary lipid elements has been shown to influence the development of coronary heart disease (Cordan et al., 2002).

All types of meat are excellent sources of monounsaturated fatty acids, which can reduce cholesterol levels in human blood. The most important monounsaturated fatty acids in meat are oleic acid and palmitoleic acid. A diet rich in polyunsaturated FA (PUFA), especially long chained $\omega-3$ FA ( $\geq$ C20), has beneficial effects on human health, e.g. in prevention of arteriosclerosis. Game meat is a potential food source that is both lean and rich in $\omega-3$ PUFA (Sampels, 2005). Currently high intakes of fat containing high amounts of SFA and MUFA in modern Western diets are associated with adverse effects on human health, such as cardiovascular diseases, obesity and diabetes (Mann, 2000).
It is not only the amount of PUFA in the food that is important, but also the ratio between n- 6 and n-3 PUFA, for which values of 1 to 4 have been recommended (Simopoulos, 2002; Anonymous, 2003). In our study, in samples of game ruminants meat this ratio varied from 1.72 in elk meat till 2.75 in deer meat, but was higher in wild boar meat Medeiros et al. (2002) reported a ratio $\omega-6: \omega-3$ in deer meat of 3.45. In bovine animals (hogs and pigs), the ratio is above 4 . Thus, it can be concluded that wild animal (except wild boar) is favourable from the point of view of healthy nutrition, and that it is less associated with a variety of health problems. Improving the dietary ratio by decreasing the $\omega-6$ fatty acid concentration and increasing the $\omega-3$ fatty acid concentration is essential for brain function and for the management of cardiovascular disease, arthritis and cancer (Simopoulos, 2002).

WHO and Wood reported that the recommended ratio PUFA : SFA must be higher than 0.4 and that in domestic animals it is too low 0.1 (Wood et al., 2003). High relative proprtions of PUFA are characteristic of all wild ruminant muscle tissue, whereas the relative proportion of PUFA in muscle tissue of wild boar is lower than in wild ruminants. In the present investigation, the PUFA:SFA ratio was higher than 0.4 in all game meat samples (range from 0.50 till 0.68). Medeiros et al. (2002) reported that the PUFA: SFA ration of beef samples was 0.38 .

To calculate the atherogenicity index (IA), Ulbricht and Southgate (1991) used the fatty acid profile. This index has a positive correlation with the risk of cardiovascular disorders._Increases in dietary levels of saturated fat, particularly $12: 0,14: 0$ and $16: 0$ (palmitic acid) have been identified as the major dietary factor responsible for raising total and LDL serum cholesterol concentrations (Howell et al., 1997). Therefore, these fatty acids are included in the formula.

Consumers are interested in the environment and the products which are produced with sustainable farming methods. Hunting of wild moose, deer, roe deer and wild boar can provide food that perfectly complements and diversifies the daily assortment of meat, which is in line with current health and dietary recommendations, low-fat and high content of essential amino acids. All meat samples are excellent sources of trace elements

\section{ACKNOWLEDGEMENTS}

The present research is partly funded by the State Research Programme "Sustainable Use of Local Resources (Earth Entrails, Forests, Food and Transport) - New Products and Technologies (NatRes)", Project No. 3 "Sustainable use of local agricultural resources for development of increased nutrition value food products (FOOD)", Subproject 3.3 "Production of high quality deer farming products under sustainable farming conditions", and the publication was supported by project "Raising Awareness and Fostering International Cooperation of the Research Institute of Biotechnology and 
Veterinary Medicine "Sigra"”, agreement

No. 2010/0197/2DP/2.1.1.2.0/10/APIA/VIAA/016.

\section{REFERENCES}

Aldai, N., Osoro, K., Barrón, L. J. R., Najera, A. I. (2006). Gas-liquid chromatographic method for analysing complex mixtures of fatty acids including conjugated linoleic acids (cis9 trans 11 and trans 10 cis 12 isomers) and long-chain (n-3 or n-6) polyunsaturated fatty acids: Application to the intramuscular fat of beef meat. J. Chrom., 1110, 133 - 139.

Anonymous (2003). Diet, Nutrition and the Prevention of Chronic Diseases. World Health Organization Report of a Joint WHO/FAO Expert Consultation, Geneva, 160 pp. Cordan, L., Watkins, B. A., Florant, G. L., Kelher, M., Rogers, L., Li, Y.(2002). Fatty acid analysis of wild ruminant tissues: Evolutionary implications for reducing diet — related chronic disease. Eur. J. Clin. Nutr., 56, 181-191.

Honikel, K. O. (2009). Composition and calories. In: Nollet, L. M., Toldra, F. Handbook of Muscle Foods Analysis. CRC Press-Book: eBook.ISBN: 978-1-4200-4530-7369-384 (accessed 22 June 2012).

Howell, W. H., McNamara D.J., Tosca M.A., Smith B.T., Gaines J.A. (1997) Plasma lipid and lipoprotein responses to dietary fat and cholesterol: A meta analysis. Amer. J. Clin. Nutr., 65, 1747-1764.

Kalafova, A., Kovačik, J., Jurčik, R., Lukač, N., Massanyi, P., Capcarova, M., Schneiderova, M., Čupka, P. (2003). Mineral profile of rabbits after experimental addition of $\mathrm{Ni}$ a Zn VII. In: Celoslovensky seminar z fyziologie živočichov, 24-25 May (pp. 124-128). Nitra, Slovak Republic.

Mann, N. (2000). Dietary lean red meat and human evolution. Eur. J. Nutr., 39, 71-79.

Medeiros, L. C., Busboon, I. R., Field, R. A., Williams, I. C., Miller, G. I., Holmes, B. (2002). Nutritional Content of Game Meat. ces.uwyo.edu/PUBS/B920R.PDF (accessed 10 July 2012).

Paleari, M. A., Moretti, V. M., Beretta, G., Mentasti, T., Bersanni, C. (2003). Cured products from different animal species. Meat Sci., 63 (4), 485-489.
Petkov, R. (1986). Fatty acid content of the lipid fraction of the meat from deer and roe deer. Vet. Med. Nauki, 23 (1), 53-57 (in Bulgarian).

Rule, D. C., Broughton, K. S., Shellito, S. M., Maiorano, G. (2002). Comparison of muscle fatty acid profiles and cholesterol concentrations of bison, beef cattle, elk, and chicken. J. Animal Sci., 80, 1202-1211.

Samples, S. (2005). Fatty acids and antioxidants of reindeer and red deer Emphasis on animal nutrition and consequent meat quality. Doctoral dissertation. Uppsala: Swedish University of Agricultural Sciences. 62 pp. http://pub.epsilon.slu.se/800/1/Avhandling_nr_31_2005.pdf

Simopoulos, A. P. (2002). The importance of the ratio of omega-6/omega-3 essential fatty acids. Biomed. Pharmacother., 56, 365-379.

Soriano A., Cruz B., Gomez L., Mariscal C., Ruiz A.G. (2006). Proteolysis, physicochemicalcharacteristics and free fatty acid composition of dry sausages made with deer (Cervus elaphus) or wild boar (Sus scrofa) meat: A preliminary study. Food Chem., 96 (2), 173-184.

Ulbricht, T. L. V., Southgate, D. A. T. (1991). Coronary heart disease: Seven dietary factors. Lancet, 338, 985-992.

Vergara, H., Gallego, L., Garcia, A., Landete-Castillejos, T. (2003). Conservation of Cervus elaphus meat in modified atmospheres. Meat Sci., 65 (2), 779-783.

Wood, J. D, Richardson, R. I,. Nute, G. R, Fisher, A. V., Campo, M. M., Kasapidou, E. (2003). Effects of fatty acids on meat quality: A review. Meat Sci., 66, 21-32.

Wood, J. D., Enser, M. (2004). Factors influencing fatty acids in meat and the role of antioxidants in improving meat quality. Brit. J. Nutr., 66 (1), 21-32.

Young, O. A., Frost, D. A., West, J., Braggins, T. J. (2001). Analytical methods. In: Hui, Y. H., Wai-Kit, N., Rogers, R. W., Young, O. A. Meat Science and Applications. Chapter 5 (pp. 103-126). New York: Marcel Dekker, Inc.

Шманенов Н. А., Алиев Ф. Ф. (1973). Методические указания по исследованию липидного обмена у сельскохозяйственных животных [Guidelines for the Investigation of Lipid Metabolism in Farm Animals]. Боровск. 115 (in Russian).

\section{SAVVAḶAS DZĪVNIEKU GALLAS UZTURVĒRTĪBA}

Rakstā analizēts viens no vērtīgākajiem pārtikas produktiem — gaḷa, tās uzturvērtību nosaka neaizstājamās aminoskābes, taukskābes, vitamīni, minerālvielas. Darba mērķis bija salīdzināt uzturvērtību nomedītu savvaḷas dzīvnieku — aḷnu, savvaļas briežu, audzētavās audzētu briežu, stirnu, mežacūku un mājdzīvnieku - ar liellopu un cūku gạ̣as paraugiem (pētījumā tika izmantoti gaḷas paraugi no muguras garā muskuḷa (m. logissimus lumborum)). Veikto pētījumu rezultāti liecina, ka savvaḷas dzīvnieku gaḷas paraugi, salīdzinājumā ar mājdzīvnieku gal̦u, ir ar augstāku olbaltumvielu un būtiski vērtīgāku taukskābju sastāvu. Savvaḷā nomedītu aḷnu, briežu, stirnu un mežacūku gaļa var lieliski papildināt un dažādot ikdienas gaḷas sortimentu, saskaņā ar pašreizējiem veselīga uztura ieteikumiem — zemu tauku un augstu neaizvietojamo aminoskābju saturu. Visi medījuma gaḷas veidi ir lielisks mikroelementu avots. 